\title{
GRANGER CAUSALITY POLA KONSUMSI IKAN DI ACEH TENGAH MENGGUNAKAN ANALISISI VECTOR ERROR CORRECTION MODEL (VECM)
}

\section{GRANGER CAUSALITY ON FISH CONSUMPTION PATTERNS IN CENTRAL ACEH USING ANALYSIS OF VECTOR ERROR CORRECTION MODEL (VECM)}

\author{
Yasrizal $^{1 *}$, Nabila Ukhty ${ }^{2}$ \\ ${ }^{1}$ Program Studi Ekonomi Pembangunan, Fakultas Ekonomi, Universitas Teuku Umar \\ ${ }^{2}$ Program Studi Perikanan, Fakultas Perikanan dan Ilmu Kelautan, Universitas Teuku Umar \\ *Korespondensi: yasrizal@utu.ac.id
}

\begin{abstract}
Development of human resources is very important in promoting economic growth, because humans are not only objects in development but also play a role as a subject. Stunting is a major problem that inhibits the quality of human resources, to reduce the amount of human development that lives by stunting is to increase the consumption of protein contained in fish. This study aimed to determine the pattern of fish consumption in Central Aceh and the variables that affect fish consumption. The analytical model used is the granger causality analysis, through the Vector Error Correction Model (VECM) analysis model. The results of this study indicate that the pattern of fish consumption in Central Aceh was not only influenced by income, but also influenced by the amount of chicken meat and egg consumption Increased income does not have a positive effect on increasing fish consumption but affects the amount of chicken meat and egg consumption. To increase the amount of fish consumption in Central Aceh, efforts to increase the amount of fish supply through local fish farming activities and the socialization of fish eating.
\end{abstract}

Keywords: Fish Consumption Pattern, Granger Causality, VECM

\section{Pendahuluan}

Investasi sumberdaya manusia sangat penting dalam pembangunan ekonomi (Wright and Mcmahan 2011). Manusia bukan hanya sebagai sabjek dalam pembangunan namun juga sebagai objek atau pelaku dalam pembangunan ekonomi (Aimon 2012). sumberdaya manusia yang produktif sangat tergantung pada kondisi kesehatan dan tingkat pendidikan, lama pendidikan pendidikan saja tidak cukup untuk mendongkrak tingkat produktivitas jika asupan gizi yang diberikan sejak mereka lahir tidak cukup. Asupan gizi yang tidak cukup akan membuat manusia berkembang dalam kondisi stanting (Kusuma, Khomsan, dan Kustiyah 2017). Stanting telah menjadi masalah utama dalam pembangunan sumberdaya manusia, status ekonomi dan konsumsi ikan telah mampu mengurangi tingkat stanting (Nurjanah, Hidayat, dan Mawarti Perdana 2015).

Konsumsi ikan di Aceh tengah berada pada 31,1 Kg/per kapita atau dibawah rata-rata tingkat konsumsi ikan Provinsi Aceh yang mencapai 54 kg/per kapita (BPS Aceh 2019). Tingkat konsumsi ikan dipengaruhi oleh tingkat pendapatan, harga dan elastisitas barang pengganti (Lestari, Haryanto, dan Marwardi 2009). Kondisi ketersediaan produksi ikan juga ikut mempengaruhi konsumsi ikan. 
kekurangan konsumsi ikan mengakibatkan meningkatnya konsumsi barang pengganti (subtitusi) ikan, seperti daging ayam dan telor ayam (Pratisti 2017).

Pendapatan merupakan salah satu variabel penting dalam meningkatkan konsumsi masyarakat, hubungan pendapatan dengan konsumsi adalah positif (Pusat Data dan Sistem Informasi Pertanian 2014). Semakin tinggi tingkat pendapatan, semakin tinggi jumlah konsumsi masyarakat (Parsaulian, Aimon, dan Anis 2013). Pola konsumsi masyarakat masyarakat terdiri dari barang pokok dan barang pelengkap. barang pokok terdiri atas makanan dan non makanan, barang pokok makanan terdiri dari beras, sayur-sayuran, ikan dll (Yasrizal 2018). konsumsi ikan sangat dipengaruhi oleh tingkat pendapatan yang dimiliki masyarakat, karena protein yang dimiliki oleh ikan tidak sama dengan protein yang dihasilkan dari barang pengganti ikan (Asfar, Tawali, dan Mahendradatta 2014).

Ikan merupakan barang normal, pengaruh harga akan mempengaruhi pola konsumsi ikan dalam masyarakat ketika harga ikan naik, masyarakat menggantikananya dengan ikan olahan, telor ayam, atau daging ayam (Arthatiani, Kusnadi, dan Harianto 2018). Masyarakat yang hidup dibawah garis kemiskinan cenderung menggantikannya dengan telor ayam atau tidak mengkonsumsi ikan (Putranto dan Taofik 2015).

Untuk milihat pola konsumsi ikan pada masyarakat Aceh Tengah, penelitian ini menggunakan model Vector Error Correction Model (VECM). Pada pemodelan ini analisis granger Causality bertujuan untuk melihat hubungan keterkaitan antar variabel, tidak ada yang menjadi varibel bebas atau variabel terikat, setiap variabel memiliki keterkaitan dengan variabel dan hubungan kausalitas jangka pendik dan jangka panjang (Kilian and Lütkepohl 2017)(Andrei and Andrei 2015) .

\section{Metodologi Penelitian}

Penelitian ini merupakan penelitian kuantitatif, jenis data dalam penelitian ini adalah data runtun waktu. yang terdiri dari tingkat konsumsi ikan, pendapatan masyarakat, konsumsi telor ayam dan daging ayam. Metode analisis data yang digunakan adalah melakukan uji stasionelitas jika data stasioner maka pengujian akan dilanjutkan dengan Model Vector Autoregressive (VAR), jika data tidak stasioner pada tingkat lever namun stasioner di defferencing data maka digungakan alat analisis VECM dengan menggunakan model analisis berikut:

$$
Y_{t}=c+A_{0}+A_{1} Y_{t-1}+A_{2} Y_{t-2}+\ldots+A_{p} Y_{t-p}+e_{t}
$$


Tahapan analisis dapat dilihat pada Gambar 1 berikut ini:

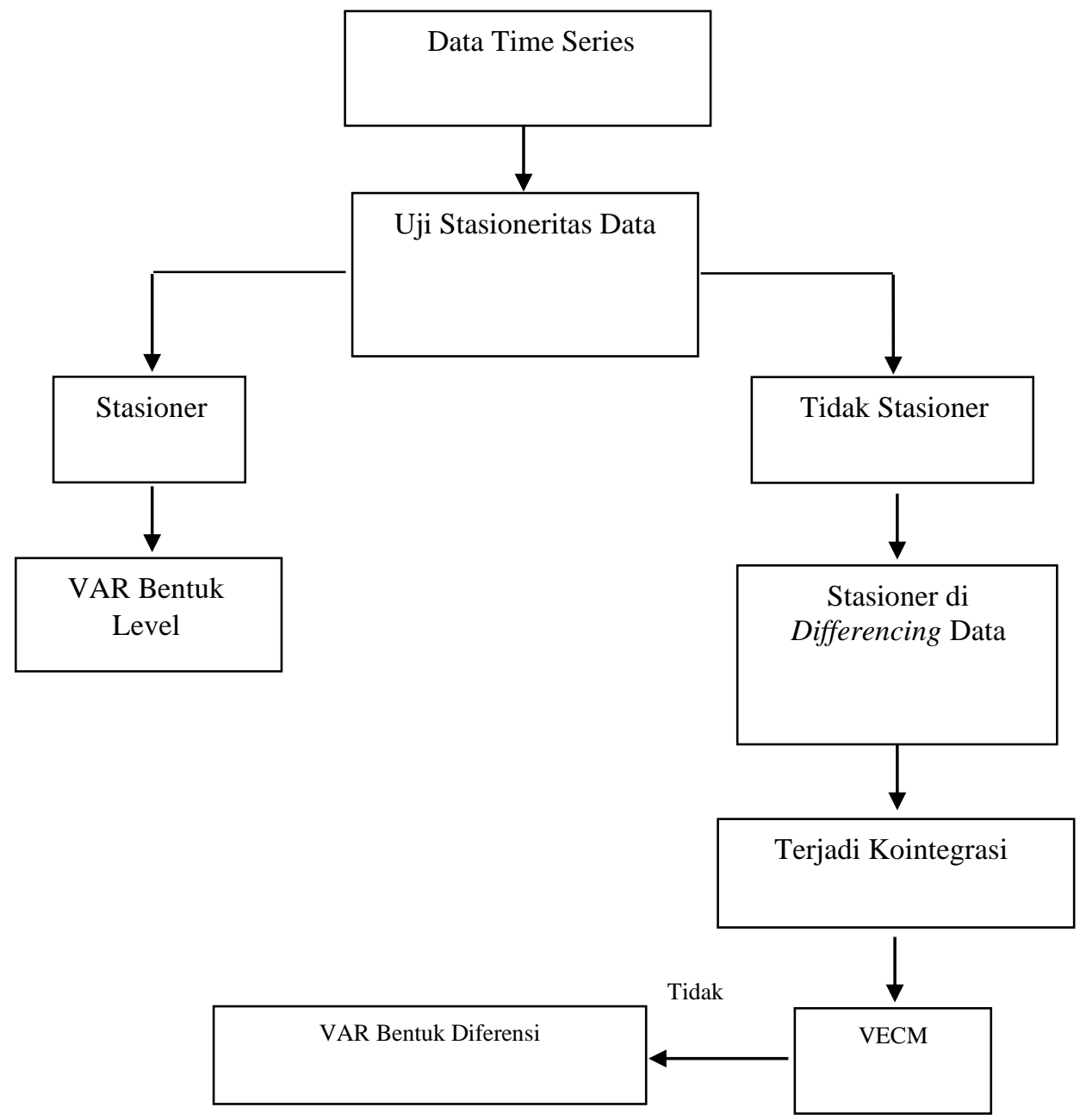

Gambar 1. Tahapan Analisis menggunakan VECM

\section{Uji Lag Optimal}

Ada beberapa metode untuk menentukan panjang lag optimal salah satunya nilai Akaike Information Criterion (AIC) dengan persamaan sebagai berikut:

$$
A I C=\ln \left(\frac{R S S}{n}\right)+\frac{2 k}{n}
$$

dimana:

$$
\begin{array}{ll}
R S S & : \text { jumlah residual kuadrat } \\
k & : \text { jumlah variabel parameter estimasi } \\
n & : \text { jumlah observasi }
\end{array}
$$

\section{Uji Kointegrasi}

Pengujian kointegrasi dengan menggunakan metode Johansen's Multivariate Cointegration Test yaitu: 


$$
Y_{t}=A_{1} Y_{t-1}+\ldots \ldots \ldots+A_{k} Y_{t-k}+\Phi D_{t}+\mu+\varepsilon_{t},
$$

dimana:

$$
\begin{array}{ll}
A_{i} & : n \times n \text { koefisien matriks } \\
\mu & : \text { konstanta } \\
D_{t} & : \text { peubah boneka musiman yang } \\
& \text { ortogonal terhadap konstanta } \mu \\
\varepsilon t & : \text { diasumsikan independen }
\end{array}
$$

\section{Uji Kausalitas}

Uji kausalitas adalah pengujian untuk menentukan hubungan sebab akibat antara variabel dalam sistem VAR. Jika terjadi kausalitas dalam perilaku ekonomi maka di dalam model ekonometrika ini tidak terdapat variabel eksogen. Hubungan sebab-akibat ini bisa diuji dengan menggunakan uji kusalitas Granger, dengan statistik uji sebagai berikut:

$$
F_{\text {hitung }}=(n-k) \frac{\left(R S S_{R}-R S S_{U R}\right)}{m\left(R S S_{U R}\right)} \text {, }
$$

dimana:

$$
\begin{array}{ll}
R S S_{R} & : \text { jumlah residual kuadrat } \\
R S S_{U R} & : \text { jumlah total akar } \\
n & : \text { jumlah observasi }
\end{array}
$$

Kriteria pengujian jika nilai $F_{\text {hitung }}$ lebih besar dari nilai $F_{\text {tabel }}$ dengan derajat bebas $k-1, n-k$ terdapat hubungan kausalitas dan sebaliknya

\section{Impulse Response}

Secara individual di dalam penggunaan model VAR tidak terdapat hasi interprestasi data, maka para ahli ekonometrika menggunakan analisis impulse response. Analisisi ini dianggap penting karena mampu memprediksi goncanga (shock) atau gangguan akibat dari kegiatan ekonomi yang tidak stabil (Asari et al. 2011).

\section{Variance Decomposition}

Analisis Variance Decomposition diperlukan karena menggambarkan setiap varian terjadi shocs. Variance Decomposition bertujuan untuk memprediksi besarnya sumbangan persentase varian perubahan variabel karena adanya perubahan tertentu dalam variabel.

\section{Hasil dan Pembahasan}

Untuk melakukan pengujian model VECM, maka langkah pertama dilakukan adalah melakukan pengujian stasioneritas. Variabel consumsi ikan, daging ayam, variabel pendapatan dan konsumsi telor ayam di lakukan pengujian, jika 
dinyatakan lulus uji stasioneritas maka dilakukan pengujiah selanjutnya. Hasil uji secara stasioneritas dapat dilihat pada Tabel 1.

Tabel 1. Pengujian stasioneritas

\begin{tabular}{llll}
\hline No & Variabel & \multicolumn{2}{c}{ PP } \\
\cline { 3 - 4 } & & At Lever & $1^{\mathrm{Fd}}$ \\
\hline 1 & C-Ikan & -8.000549 & \\
& & 0.0000 & \\
2 & D-Ayam & -10.04501 & \\
3 & pendapatan & 0.0000 & -10.19804 \\
4 & T-Ayam & & 0.0000 \\
& & -7.390186 & \\
\hline
\end{tabular}

Dari hasil pengujian diatas menunjukkan bahwa nilai variabel C-ikan, DAyam dan T-ayam menunjukkan hasil bawah stasioner pada At-Lever dan variabel pendapatan stasioner pada $1^{\text {st }}$ different.

\section{Penentuan lag optimal}

Pengujian lag optimal dengan menggunakan kriteria AIC dengan hasil sebagai berikut

Tabel 2. Nilai AIC setelah melakukan pengujian Differencing

\begin{tabular}{ll}
\hline LAG & AIC \\
\hline 0 & 46.38007 \\
1 & $42.79633^{*}$ \\
2 & 42.97218 \\
3 & 43.09754 \\
4 & 43.25093 \\
5 & 43.34787 \\
\hline
\end{tabular}

Hasil pengujian AIC pada tabel 2 diatas, nilai AIC yang diperoleh dapat kita jabarkan bahwa lag kriteria yang dipilih untuk analisis pola konsumsi ikan di Aceh Tengah setelah differencing pada tingkat satu dengan mengambil nilai terkecil dan nilai absolutnya adalah nilai AIC pada lag 1 hasil ini terlihat tanda bintang setelah pengujian. Untuk tahap analisis selanjutnya lag yang dipilih adalah lag 1.

\section{Uji Kointegrasi}

Untuk melihat hasil uji kointegrasi metode yang dilakukan adalah dengan melakukan pengujian Trance Statistic dan Max. Data hasil pengujian pada tabel 3 dibawah ini menjukkan nilai Trance Statistic setelah di uji menggunakan alat uji statistik. 
Tabel 3. Nilai Trace Statistic dan Max-Eigen Statistic

\begin{tabular}{cccccc}
\hline $\begin{array}{c}\text { Hypothesized } \\
\text { No. of CE(s) }\end{array}$ & Eigenvalue & $\begin{array}{c}\text { Trace } \\
\text { Statistic }\end{array}$ & $\begin{array}{c}\text { Max-Eigen } \\
\text { Satistic }\end{array}$ & $\begin{array}{c}0,05 \\
\text { Critical } \\
\text { Value }\end{array}$ & Prob.** \\
\hline None $*$ & 0.333397 & 106.2115 & 39.74489 & 63.87610 & 0.0000 \\
At most $1 *$ & 0.329223 & 66.46659 & 39.13316 & 42.91525 & 0.0001 \\
At most 2* & 0.183702 & 27.33343 & 19.89159 & 25.87211 & 0.0327 \\
At most 3 & 0.073126 & 7.441837 & 7.441837 & 12.51798 & 0.3007 \\
\hline
\end{tabular}

Bedasarkah analisis data pada tabel 3 diatas menunjukkan bahwa variabel endogen pada none, at most 1 dan at most 2 nilai kritis < nilai Trance Statistic dan Max-Eigen Statistic maka dapat disimpulkan bahwa untuk variabel endogen pada lag 0, lag 1 dan lag 2 terjadi hubungan kointegrasi atau terima $\mathrm{H}_{0}$, namun pada pengujian untuk at most 3 pada lag 3 variabel endogen dengan hasil pengujian nilai kritis > nilai Trance Statistic dan Max-Eigen Statistic maka pada lag 5 variabel endogen tidak memiliki hubungan kointegrasi atau tolak $\mathrm{H}_{0}$

\section{Estimasi Model}

Setelah melakukan pengujian analisis kointegrasi antara variabel maka hasil analisinya membentuk sebuah model Vector Error Correction Model (VECM) berikut ini:

$$
\begin{aligned}
& \text { C_IKAN }=0.185740338837 * \text { C_IKAN }(-1)+0.0318302735229 * \text { C_IKAN }(-2)+ \\
& 0.650479301687 * \text { D_AYAM(-1) + 0.546855243528*D_AYAM(-2) - } \\
& \text { 8.02181449229e-07*PENDAPATN(-1) + 8.88240824455e- } \\
& 07 * \text { PENDAPATN(-2) - 0.00590281882364*T_AYAM(-1) + } \\
& 0.0284309202896 * \mathrm{~T} \_\mathrm{AY} \text { AM }(-2)+5.58051055594 \\
& \text { D_AYAM }=-0.00481939459944 * \text { C_IKAN }(-1)+ \\
& 0.00898367498937 * \text { C_IKAN(-2) }-0.120965094575 * \text { D_AYAM(-1) + } \\
& 0.137337343967 * \text { D_AYAM }(-2)+2.47052725068 \mathrm{e}- \\
& \text { 07*PENDAPATN(-1) - 1.57288469513e-07*PENDAPATN }(-2)+ \\
& 0.00670504356914 * \mathrm{~T} \_A Y A M(-1)-0.000945312418548 * \mathrm{~T} \_A Y A M(- \\
& \text { 2) }+0.826334541552
\end{aligned}
$$

PENDAPATN $=1947.7086527 *$ C_IKAN(-1) - 3526.9643228*C_IKAN(-2) + 29482.9337771*D_AYAM(-1) - 6094.31509208*D_AYAM(-2) + $0.960203141303 *$ PENDAPATN $(-1)+$ $0.0317696591173 *$ PENDAPATN(-2) - 1155.91061852*T_AYAM(1) +3199.38846894*T_AYAM(-2) - 31305.0019161

$$
\begin{array}{r}
\text { T_AYAM }=0.686833712675 * \text { C_IKAN }(-1)+0.29764872248 * \text { C_IKAN }(-2)+ \\
1.1715535243 * \text { D_AYAM(-1) + 3.66109199042*D_AYAM(-2) - }
\end{array}
$$




$$
\begin{aligned}
& \text { 7.31139318893e-06*PENDAPATN(-1) + 5.39423047387e- } \\
& \text { 06*PENDAPATN(-2) + 0.110560150166*T_AYAM(-1) + } \\
& 0.113124754443 * \text { T_AYAM(-2) + 16.8385244482 }
\end{aligned}
$$

\section{Impulse Response}

Kurva dibawah ini menunjukkan hasil Analisis impulse response tujuannya untuk melacak respon dari variabel endogen dalam penggunanaan model VECM disebabkan terjadinya gangguan (shocks) atau adanya terjadi perubahan dari variabel mengakibatkan variabel yang lain juga ikut berubah. Hasil analisis impulse response dapat dilihat pada Gambar 2.

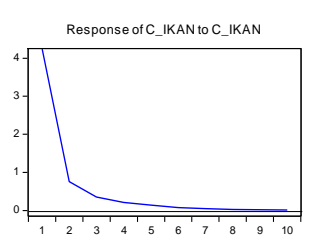

Response of CIKAN to D AYAM

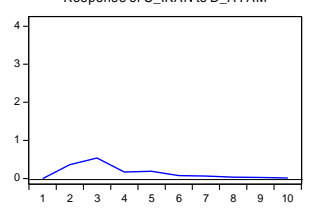

Response of D_AYAMto C IKAN

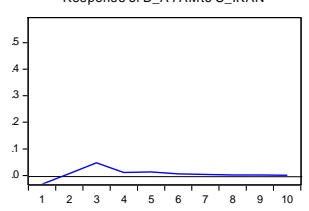

Response ofPENDAPATN to C IIKAN

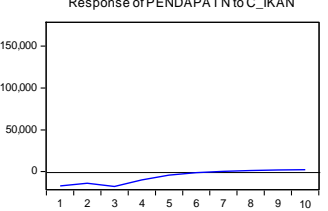

Response of T_AYAMto C_IKAN

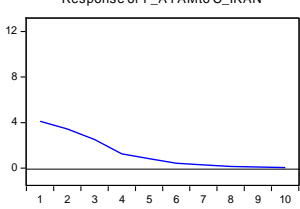

Response of D_AYAMTO D AYYM
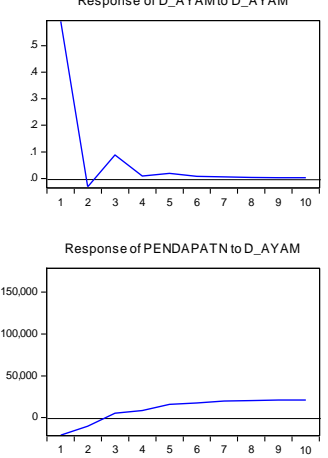

Response of T_AYAMto D_AYAM

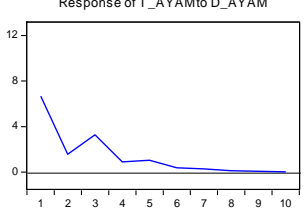

Gambar 2. Kurva Impulse Response
Response otC IKANto PenDaPatn

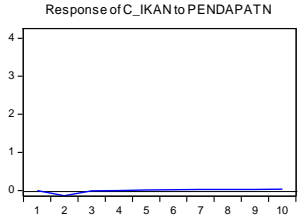

Response of _IKAN to T_AYAM

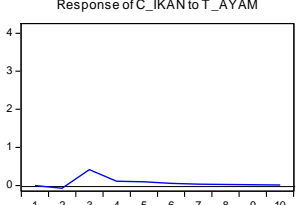

Response of D_AYAMto PENDAPATN
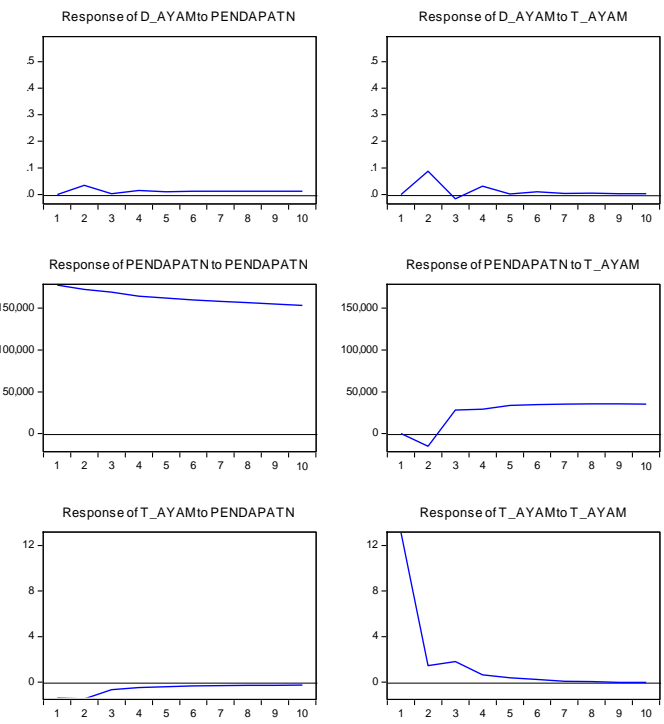

Hasil impulse response dampak goncangan ekonomi terhadap variabel konsumsi ikan, konsumsi telor ayam dan daging ayam terjadi selama tiga periode mulai dari periode pertama hingga ke periode ke tiga, terlihat pada periode keempat sampai kesepuluh konsumsi ikan mulai stabil. Dampak shock disebabkan oleh menurunnya variabel pendapatan masyarakat selama 4 periode. Sehingga secara bersamaan variabel konsumsi ikan dipengaruhi oleh jumlah pendapatan dan konsumsi harga barang pengganti.

\section{Variance Decomposition}

Analisis Variance Decomposition dilakukan untuk melihat besarnya pergerakan dari suatu variabel yang dipengaruhi oleh goncangan (shock) dari variabel itu sendiri serta melalukan analisis perbandingan dengan variabel yang 
lain dalam suatu persamaan. Hasil uji Variance Decomposition dapat dilihat pada Gambar 3.

Response to Cholesky One S.D. (d.f. adjusted) Innovations
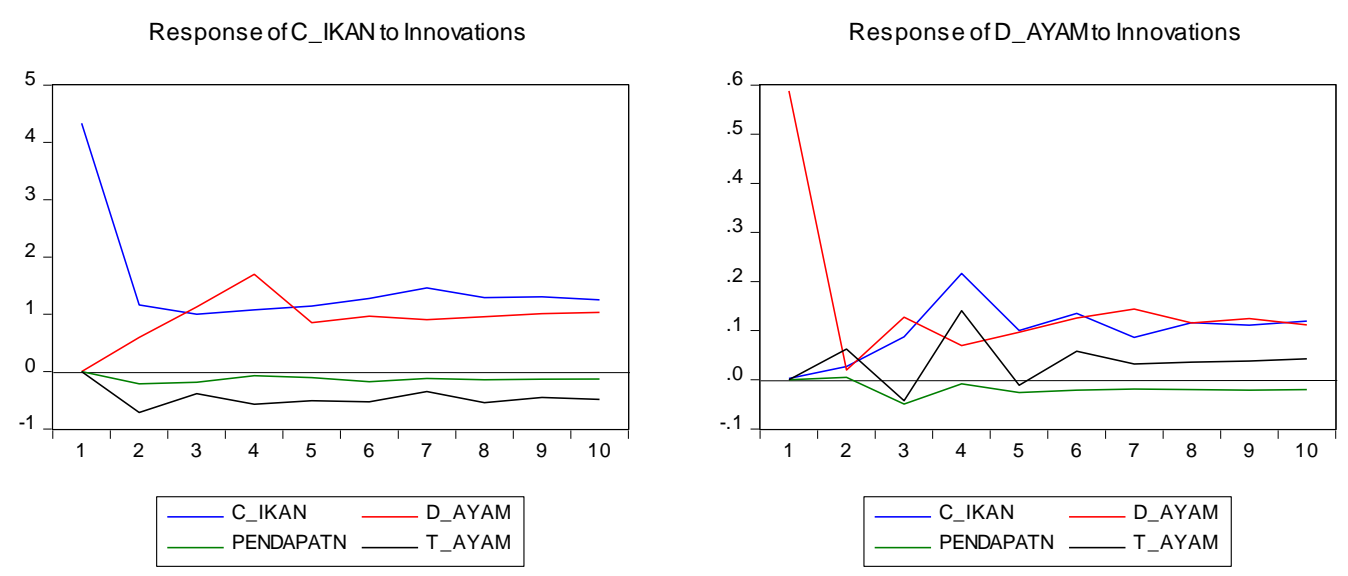

Response of PENDAPATN to Innovations
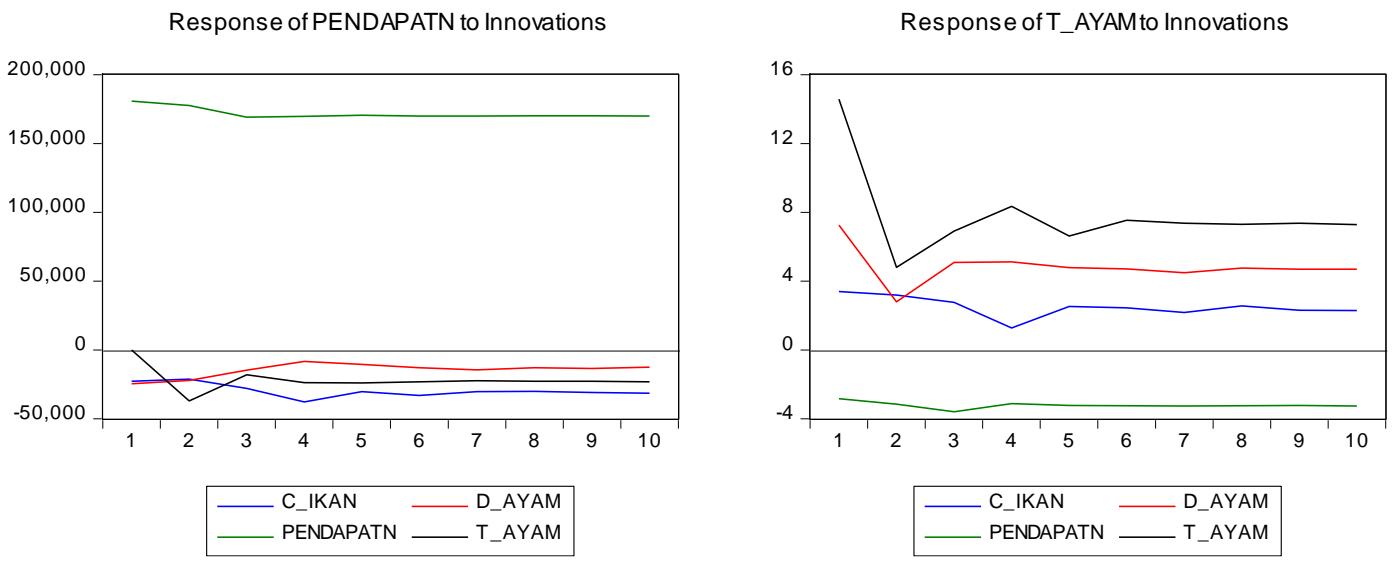

Gambar 3. Kurva Variance Decomposition Response Pola Konsumsi Ikan.

Pada Gambar 3 dapat dilihat hasil dari Analisis impulse response antara variabel konsumsi ikan, konsumsi daging ayam, telor ayam dan pendapatan. Dampak dari goncangan variabel pendapatan mempengaruhi pola konsumsi ikan ikut tergoncang (Shock) selama empat veriode, secara bersamaan juga mempengaruhi konsumsi telor dan saging ayam. Pola konsumsi ikan di Aceh Tengah secara bersamaan dikonsumsi oleh masyarakat. meningkatnya pendapatan mempengaruhi positif signifikan secara bersamaan variabel konsumsi ikan dan barang pengganti konsumsi ikan seperti telor ayam dan daging ayam. Variance Decomposition Response pola konsumsi ikan dapat dlihat pada Tabel 4. 
Tabel 4. Variance Decomposition Response Pola Konsumsi Ikan

\begin{tabular}{crrrr}
\hline \hline Respon Of C-Ikan Period & C_IKAN & D_AYAMPENDAPATN T_AYAM \\
\hline \hline 1 & 4.333733 & 0.000000 & 0.000000 & 0.000000 \\
2 & 1.161634 & 0.599412 & -0.215938 & -0.713885 \\
3 & 1.000287 & 1.126821 & -0.184640 & -0.383116 \\
4 & 1.078856 & 1.697690 & -0.069857 & -0.569330 \\
5 & 1.144501 & 0.852258 & -0.107498 & -0.506981 \\
6 & 1.276251 & 0.968232 & -0.174998 & -0.528864 \\
7 & 1.462889 & 0.905439 & -0.118239 & -0.349002 \\
8 & 1.290086 & 0.957449 & -0.141946 & -0.540531 \\
9 & 1.303423 & 1.012605 & -0.135318 & -0.451144 \\
10 & 1.252267 & 1.034886 & -0.130564 & -0.486506 \\
\hline \hline Response of D_AYAM Period & C_IKAN & D_AYAMPENDAPATN T_AYAM \\
\hline \hline 1 & 0.002768 & 0.588283 & 0.000000 & 0.000000 \\
2 & 0.026894 & 0.019676 & 0.004712 & 0.062415 \\
3 & 0.087336 & 0.127438 & -0.049216 & -0.042897 \\
4 & 0.216365 & 0.069750 & -0.008618 & 0.140529 \\
5 & 0.100434 & 0.097102 & -0.026070 & -0.011172 \\
6 & 0.135308 & 0.125480 & -0.021107 & 0.058212 \\
7 & 0.086083 & 0.143712 & -0.018707 & 0.032056 \\
8 & 0.116163 & 0.115669 & -0.020001 & 0.036169 \\
9 & 0.111416 & 0.124327 & -0.021351 & 0.037908 \\
10 & 0.119673 & 0.111778 & -0.020170 & 0.042658 \\
\hline \hline
\end{tabular}

Response of PENDAPATN

Period

C_IKAN D_AYAMPENDAPATN T_AYAM

\begin{tabular}{rrrrr}
\hline \hline 1 & -22832.67 & -24571.24 & 180637.2 & 0.000000 \\
2 & -21177.24 & -22194.71 & 177556.8 & -37085.98 \\
3 & -28036.12 & -14660.66 & 168999.1 & -18008.08 \\
4 & -37871.91 & -8475.296 & 169647.5 & -23735.42 \\
5 & -30410.46 & -10613.76 & 170457.0 & -23926.38 \\
6 & -33073.58 & -12897.68 & 169944.1 & -23204.76 \\
7 & -30348.79 & -14538.93 & 169836.8 & -22494.44 \\
8 & -30109.04 & -13030.09 & 169964.4 & -22866.80 \\
9 & -31015.78 & -13547.03 & 169992.8 & -22796.54 \\
10 & -31430.79 & -12633.75 & 169914.2 & -23189.67 \\
\hline \hline
\end{tabular}

\begin{tabular}{|c|c|c|c|c|}
\hline \multirow{2}{*}{$\begin{array}{c}\text { Response of T-AYAM Period } \\
1\end{array}$} & \multicolumn{4}{|c|}{ C_IKAN D_AYAMPENDAPATN T_AYAM } \\
\hline & 3.39 & 7.24 & -2.8 & 14.57468 \\
\hline 2 & 3.180081 & 2.793588 & -3.159349 & 4.805117 \\
\hline 3 & 2.757034 & 5.085666 & -3.593849 & 6.908766 \\
\hline 4 & 1.277934 & 5.115758 & -3.125274 & 8.343817 \\
\hline 5 & 2.528349 & 4.786301 & -3.230671 & 6.618445 \\
\hline 6 & 2.445015 & 4.707203 & -3.253741 & 7.527251 \\
\hline 7 & 2.170232 & 4.488004 & -3.272209 & 7.352677 \\
\hline
\end{tabular}




$\begin{array}{ccccc}8 & 2.552227 & 4.754453 & -3.253482 & 7.297947 \\ 9 & 2.297740 & 4.687949 & -3.239156 & 7.364750 \\ 10 & 2.281872 & 4.690911 & -3.263449 & 7.280417\end{array}$

Cholesky Ordering: C_IKAN D_AYAM PENDAPATN T_AYAM

\section{Kesimpulan}

1. Pola konsumsi ikan pada periode pertama dipengaruhi oleh dirinya sebesar 100 persen, pada periode kedua hingga ke sepuluh dipengaruhi secara bersamaan oleh variabel konsumsi daging ayam, telor ayam dan pendapatan. Hubungan antara variabel daging ayam terhadap konsumsi ikan di Aceh Tengah adalah positif namun variabel pendapatan dan telor ayam adalah negatif, yang artinya jika pendapatan meningkat dan konsumsi telor meningkat akan mengurangi konsumsi ikan, namun jika konsumsi daging ayam meningkat maka konsumsi ikan juga meningkat.

2. Hubungan konsumsi daging ayam dengan ikan adalah positif, namun hubungan variabel daging ayam dengan telor hubungannya negatif pada periode ketiga dan keenam. Hubungan konsumsi daging ayam dengan pendapatan juga negatif.

3. Hubungan konsumsi telor ayam dengan variabel konsumsi daging ikan dan konsumsi daging ayam adalah positif namun hubungan dengan pendapatan negatif.

4. Masyarakat Aceh Tengah hidup pada dataran tinggi, ketersediaan ikan terbatas dibandingkan dengan ketersediaan daging ayam dan telor ayam, sehingga pengaruh pendapatan masyarakat tidak terlalu berpengaruh terhadap tingkat konsumsi ikan, namun berpengaruh terhadap konsumsi makanan pengganti ikan seperti daging ayam, telor ayam dan variabel lainnya yang tidak diteliti didalam model ini.

5. Untuk meningkatkan konsumsi ikan kepada masyarakat Aceh Tengah perlu perlu upaya meningkatkan pemasok dari luar daerah, budidaya ikan air tawar dan kompanye pentingnya konsumsi ikan.

\section{Daftar Pustaka}

Aimon, Hasdi. 2012. Produktivitas, investasi sumberdaya manusia, investasi fisik, kesempatan kerja terhadap kemiskinan dan pertumbuhan ekonomi di indonesia. Jurnal Kajian Ekonomi.

Andrei, Dalina Maria, and Liviu C. Andrei. 2015. "Vector Error Correction Model in Explaining the Association of Some Macroeconomic Variables in Romania." Procedia Economics and Finance.

Arthatiani, Freshty Yulia, Nunung Kusnadi, and Harianto Harianto. 2018. Analisis pola konsumsi dan model permintaan ikan menurut karakteristik rumah tangga di indonesia. Jurnal Sosial Ekonomi Kelautan dan Perikanan.

Asari, Fadli Fizari Abu Hassan et al. 2011. "A Vector Error Correction Model ( 
VECM ) Approach in Explaining the Relationship Between Interest Rate and Inflation Towards Exchange Rate Volatility in Malaysia." World Applied Sciences Journal.

Asfar, Muh, Abu Bakar Tawali, and Meta Mahendradatta. 2014. "Potensi Ikan Gabus (Channa Striata) Sebagai Sumber Makanan Kesehatan- Review.” In Prosiding Seminar Nasional Teknologi Industri II,.

Kilian, Lutz, and Helmut Lütkepohl. 2017. "Vector Error Correction Models." In Structural Vector Autoregressive Analysis,.

Kusuma, Rendra, Ali Khomsan, and Lilik Kustiyah. 2017. Konsumsi ikan pada ibu hamil dan kaitannya dengan outcome kelahiran. Media Kesehatan Masyarakat Indonesia.

Lestari, Endang Wiji, Idha Haryanto, and S Marwardi. 2009. "Konsumsi Kopi Masyarakat Perkotaan Dan Faktor-Faktor Yang Berpengaruh: Kasus Di Kabupaten Jember.” Pelita Perkebunan.

Nurjanah, Nurjanah, Taufik Hidayat, and Silvia Mawarti Perdana. 2015. "Analisis Faktor Faktor Yang Mempengaruhi Konsumsi Ikan Pada Wanita Dewasa Indonesia." Jurnal Pengolahan Hasil Perikanan Indonesia.

Parsaulian, Baginda, Hasdi Aimon, and Ali Anis. 2013. Analisis konsumsi masyarakat di indonesia. Jurnal Kajian Ekonomi.

Pratisti, Cahyani. 2017. "Model Konsumsi Ikan Pada Konsumen Muda (Studi Di Yogyakarta)." Jurnal Riset Ekonomi Manajemen (REKOMEN).

Pusat Data dan Sistem Informasi Pertanian. 2014. "Buletin Konsumsi Pangan." 2014.

Putranto, Kelik, and Ahmad Taofik. 2015. "Pola Diversifikasi Konsumsi Pangan Masyarakat Adat Kampung Cireundeu Kota Cimahi Jawa Barat.” Jurnal Istek.

Sirajuddin, Sumitra, and Trina Astuti. 2018. Kementrian Kesehatan Republik Indonesia Survey Konsumsi Pangan.

Sitepu, Rasidin Karo-karo. 2007. "Dampak Investasi Sumberdaya Manusia Dan Transfer Pendapatan Terhadap Distribusi Pendapatan Dan Kemiskinan DI Indonesia." Thesis.

Wright, Patrick M., and Gary C. Mcmahan. 2011. "Exploring Human Capital: Putting 'human' Back into Strategic Human Resource Management." Human Resource Management Journal.

Yasrizal. 2018. Household welfare in aceh province the impact of non-food commodity inflation on changes of household welfare in aceh province. : 5666. 